\title{
Sobrevivência in vitro de blastocistos Mus domesticus domesticus vitrificados em macro ou microvolume de crioprotetor
}

\author{
ALEXANDER NIVIA OSUNA \\ José Luiz Rodrigues (Orientador - UFRGS)
}

Banca: Marcelo Bertolini (UDESC), Alexandre Tavares Duarte de Oliveira (UFCSPA), Rui Fernando Félix Lopes (UFRGS), Adriana Bos Mikich (UFRGS)

O desenvolvimento de protocolos eficientes para a vitrificação de embriões mamíferos ainda é um desafio para os especialistas em reprodução. Soluções crioprotetoras de baixa toxicidade, associadas a técnicas seguras de envase, são fatores fundamentais para proporcionarem uma eficiente identificação e controle sanitário das amostras. Dois experimentos foram realizados para determinar a taxa de sobrevivência de embriões Mus domesticus domesticus envasados em palhetas convencionais $(0,25 \mathrm{~mL})$, na presença de uma haste metálica de ouro, empregando soluções crioprotetoras descritas para a vitrificação em microvolume. No experimento 1, avaliou-se a toxicidade da solução de desidratação (SD: PBSm + 10\% EG + 10\% PROH + 0,5 M sacarose), expondo os embriões por diferentes tempos: 1 (T1), 3 (T2) ou 10 min (T3). A toxicidade da solução de vitrificação $(\mathrm{SV}: \mathrm{PBSm}+20 \% \mathrm{EG}+20 \% \mathrm{PROH})$ foi determinada pela exposição dos embriões durante 25, 60 ou 180 seg, previamente desidratados por 1 ou 3 min. No experimento 2, avaliou-se a utilização do macrovolume (palhetas com a haste de ouro) e microvolume (micropipetas de vidro - GMP) na vitrificação dos blastocistos expostos à SV por 25 seg, previamente desidratados por 1 ou 3 min. Os dados foram analisados pelo teste Qui-Quadrado ( $\mathrm{P}<0,05)$. No experimento 1, não foi observada diferença estatística entre as taxas de eclosão dos embriões desidratados: T1 =68\% (38/56), T2=72\% (36/50), T3=71\% (39/55) e o grupo-controle, $(74 \%$ - 48/65). No entanto, houve diferença significativa $(\mathrm{P}<0,05)$ na taxa de eclosão em relação ao tempo de exposição dos embriões à SV. Os embriões desidratados por 1 ou 3 min, e expostos à SV por 25 seg, proporcionaram maiores taxas de reexpansão (79\% vs. 84\%) e de eclosão (58\% vs. 72\%), em relação aos tempos de exposição de 60 e 180 seg. No experimento 2, após a vitrificação dos embriões envasados nas palhetas com a haste de ouro, a taxa de eclosão dos blastocistos previamente desidratados por $1 \mathrm{~min}$ foi de $16 \%$ (10/64) e de $4 \%$ (2/57) quando previamente desidratados por 3 min. Por outro lado, os embriões envasados nas GMP, e previamente desidratados por $3 \mathrm{~min}$, foram os que apresentaram maior taxa de eclosão (60\% - 52/86). A vitrificação de embriões utilizando soluções crioprototetoras descritas para microvolume não foi eficiente na crioproteção dos blastocistos envasados em palhetas convencionais com a haste de ouro.

Descritores: vitrificação, blastocisto, murino, macrovolume, microvolume.

Apresentada: 26 fevereiro 2008

*Dissertação de mestrado n.489 (Especialidade: Reprodução Animal). 66f. Programa de Pós-graduação em Ciências Veterinárias [www.ufrgs.br/ ppgcv], Faculdade de Veterinária, Universidade Federal do Rio Grande do Sul (UFRGS), Porto Alegre/RS. CORRESPONDÊNCIA: A. N. Osuna [axel1058_77@hotmail.com]. 


\title{
In vitro survival of vitrified Mus domesticus domesticus blastocyst in macro or microvolume of cryoprotectant solution ${ }^{* *}$
}

\author{
ALEXANDER NIVIA OSUNA
}

José Luiz Rodrigues (Adviser - UFRGS)

Committee: Marcelo Bertolini (UDESC), Alexandre Tavares Duarte de Oliveira (UFCSPA), Rui Fernando Félix Lopes (UFRGS), Adriana Bos Mikich (UFRGS)

The development of efficient vitrification protocols for mammalian embryos still is a challenge for reproductive biologists. Low toxicity cryoprotectant solutions and safe vitrifications procedures that allow sample identification and sanitary control are fundamental factors. Two experiments were conducted to determine the survival rate of vitrified Mus domesticus domesticus embryos loaded into straws containing a metallic piece (manufactured in gold), using cryoprotectant solutions described for microvolume vitrification procedures. In Experiment 1, the toxicity of the dehydratation solution (SD: $\mathrm{PBSm}+10 \% \mathrm{EG}+10 \% \mathrm{PROH}+0,5 \mathrm{M}$ sucrose) was evaluated using three different embryo exposure times: 1 (T1), 3 (T2) or $10 \mathrm{~min}$ (T3), in addition as well as the toxicity of the vitrification solution (SV: PBSm $+20 \% \mathrm{EG}+20 \% \mathrm{PROH})$ was also tested upon embryo exposure for 25, 60 or $180 \mathrm{sec}$, previously dehydration for 1 or $3 \mathrm{~min}$. In Experiment 2, the use of macrovolume (straw with a stem of gold) or microvolume (glass micropipettes - GMP) was evaluated for the vitrification of blastocysts after exposure to SV for $25 \mathrm{sec}$ and previous dehydration for 1 or $3 \mathrm{~min}$. Data were analized by the Chi-square test $(\mathrm{P}<0,05)$. In Experiment 1, statistical differences were not observed between hatching rates of dehydrated embryos: $\mathrm{T} 1=68 \%(38 / 56), \mathrm{T} 2=72 \%$ (36/50), $\mathrm{T} 3=71 \%$ (39/55) and control group embryos, $(74 \%-48 / 65)$. However, a significant difference $(\mathrm{P}<0,05)$ was observed between hatching rates after embryos exposure to the SV. Embryos dehydrated for 1 or 3 min and exposed for $25 \mathrm{sec}$ to the SV showed higher re-expansion (79\% vs. 84\%) and hatching rates (58\% vs. 72\%) than embryos exposed to SV for 60 or $180 \mathrm{sec}$. In Experiment 2, after vitrification the embryos loaded into straws containing a metallic piece showed a hatching rate of $16 \%$ (10/64) when previouslly dehydrated for $1 \mathrm{~min}$, and 4\% (2/57) when for $3 \mathrm{~min}$. On the other hand, embryos loaded into GMP, previouslly dehydrated for $3 \mathrm{~min}$, showed a higher hatching rate, (60\% - 52/60). Embryo vitrification using a cryoprotectant solution described as suitable for microvolume was not efficient to cryoprotect blastocysts loaded into macrovolume straws containing a metallic piece.

Key words: vitrification, blastocyst, mouse, macrovolume, microvolume. 